\title{
Perlit Agregalarının Farklı Sıcaklıklarda Genleștirilmesi Üzerine Teknik Bir Analiz
}

\author{
Nükhet ŞAPCI ${ }^{* 1}$, Hakan CEYLAN ${ }^{1}$ \\ ${ }^{1}$ Isparta Uygulamalı Bilimler Üniversitesi, Teknik Bilimler MYO, İnşaat Bölümü, 32260, Isparta
}

(Alınış / Received: 10.02.2021, Kabul / Accepted: 12.03.2021)

Araştırma Makalesi

\section{Anahtar Kelimeler \\ Ham perlit, \\ Genleşme, \\ Genleștirilmiş perlit, \\ Birim hacim ağırlık}

\begin{abstract}
Özet: Perlit doğal olarak oluşan silis kökenli asidik özellikte volkanik bir kayaç türüdür. Perlitin en önemli özelliği belirli sıcaklıklarda ısıtıldığında genleşerek gözenekli hafif bir yapı oluşturmasıdır. Oluşan bu gözenekli ve hafif yapı perlite endüstriyel bir değer katmaktadır. Özellikle genleșmiș perlit yüksek ısı ve ses yalıtım özelliği olan hafif harç üretimlerinde kullanılan en hafif malzemelerden biri olup aynı zamanda yüksek ısı ve yangına karşıda en dayanıklı malzemelerden birisidir. Son yıllarda ülkemizde çok sayıda genleşmiş perlit üreten tesisler açılmıștır. Ancak bu perlitlerin genleşmesindeki etken parametrelerin neler olduğu konusunda yeterli bir bilimsel çalışmaya rastlanılmamıştır. Genellikle çalışmalar genleşmiş perlitlerin ana hammadde olarak kullanılması ile edilen ürünlerin teknik performans özelliklerini tespit etmek amaçlıdır. Bu nedenle ham perlitten genleștirilmiş perlit üretimi ve genleşmeye etken parametrelerin tespit edilmesi amacıyla bir dizi ARGE çalışması yürütülmüştür. Bu çalışmada bünye suyunu kaybetme derecesi olarak bilinen $450{ }^{\circ} \mathrm{C}$ 'den başlayarak, $1050{ }^{\circ} \mathrm{C}$ 'ye kadar 7 farklı sıcaklıkta genleştirme deneyleri yapılmıştır. Ham perlitin genleşmesini etkileyen önemli parametreler arasında, agrega tane boyutu, genleşme sıcaklığı ve genleşme süresi gelmektedir. Bu parametreler bağlamında hedef olan $250-400 \mathrm{~kg} / \mathrm{m}^{3}$ arası birim hacim ağırlık değerlerinde genleșmiș perlit malzemesi elde etmek ve en uygun üretimi yapabilmek için gerekli koşullar incelenen parametrelere göre detaylı olarak açıklanmıștır.
\end{abstract}

\section{A Technical Analysis on the Expansion of Perlite Aggregates under Different Temperatures}

\author{
Keywords \\ Raw perlite, \\ Expansion, \\ Expanded perlite, \\ Unit volume weight
}

\begin{abstract}
Perlite is a natural acidic type of silica-based volcanic rock. The most important feature of perlite is becoming a lightweight porous structure by expanding when heated at certain temperatures. This porous and lightweight structure adds an industrial value to perlite. Especially expanded perlite is one of the lightest materials used in the production of light mortar with high heat and sound insulation features, and at the same time it is one of the most durable materials against high heat and fire. In recent years, many facilities producing expanded perlite have been established in our country. However, there has not been enough study about what the effective parameters in the expansion of these perlites are. Generally, studies are aimed to determine the technical performance characteristics of the products produced by using expanded perlite as the main raw material. For this reason, a series of ArGe studies have been conducted in order to produce expanded perlite from raw perlite and determine the parameters that affect the expansion. In this study, expansion experiments were carried out at 7 different temperatures starting from 450 degrees, known as the degree of loss of body water, up to 1050 degrees. Among the important parameters affecting the expansion of raw perlite are aggregate particle size, expansion temperature and expansion time. In the context of these parameters, the required conditions for obtaining expanded perlite material with unit volume weight values between $250-400 \mathrm{~kg} / \mathrm{m}^{3}$ and making the most appropriate production are explained in detail according to the parameters examined.
\end{abstract}




\section{Giriș}

Isısal konfor ve yalıtım günümüzün en önemli teknik konularından birisi konumuna gelmiş olup, özellikle inşaat endüstrisinde kullanılan yapı elemanı ve yapı malzemelerinde aranılan temel faktör olmuştur. Bununla birlikte, deprem kuşağı üzerinde bulunan ülkemizde, binaların depreme karşı direnci bakımından önem arz eden ve binaların ölü ağırlıklarının hafifletilmesi için vazgeçilmez olan hafif malzemelerden yapılmış yapı elemanlarının kullanılması gerekmektedir. Günümüzde bu hafif malzemeler kullanılarak sağlanabilmekte olup, doğal gözenekli ve hafif agregalardan elde edilmiş hafif sıva harçları, hafif beton ve hafif yapı elemanlarının kullanımı giderek önemli bir sektör haline gelmektedir. $\mathrm{Bu}$ malzemeler arasında pomza, genleştirilmiş kil, genleştirilmiş perlit, diyatomit gibi malzemeleri görmek mümkündür.

Bunlardan perlit dünyada yıllık yaklaşık 5,8-6 milyon ton civarında üretilmekte olup ham perlit ve genleştirilmiş perlit olarak piyasaya sunulmaktadır [1].

Ülkemizde ise yılık üretimi 900 bin ton civarında olup yaklaşık yarısı ihraç edilmektedir. 2008 yılında yapılan bir araştırmaya göre Türkiye'deki perlit tüketiminin \%60'ı inşaat (sıva, hafif yapı elemanları vb.), \%20'si sanayi, \%17'si tarım ve \%3'ü diğer sektörlere aittir [1].

Türkiye'de volkanik aktiviteler sonucu oluşan perlitler 3 bölgede yoğunlaşmıștır. Bunlar; Batı Anadolu Bölgesi, Orta Anadolu Bölgesi ve Doğu Anadolu Bölgesi perlit oluşumlarıdır. Batı Anadolu perlitleri, özellikle konum olarak Türkiye'nin en iyi değerlendirilebilirlik koşullarına sahip, halen işletilmekte olan ve ülkemiz ham perlit üretiminin önemli bir kısmının bu bölgeden sağlandığı oluşumlar olarak bilinmektedir.

Perlit yüksek sıcaklıkta genleşme özelliği olan, genleştirildiğinde camsı tanelerden oluşan, köpük agregasına dönüşen, ilk hacminin 20 katına kadar genleşebilen, oldukça hafif ısı ve ses yalıtımı sağlayan volkanik bir kayaçtır [2].

Perlitlerin genleştirilmesi işlemi bu tür kayaçların oluşumları anında, bünyesine giren veya bünyesinde var olan suyun çıkışı, kayacın silikat hamurunun ısınması ile viskoz hale gelmesi anında hızlandırarak çok ince gözenekli, silikat süngeri haline dönüşmesi ile gerçekleşmektedir [3].

Yapılan bir çalışmada, Batı Anadolu perlitlerinin efektif su oranları çok düşük olup endüstriyel alanda optimal genleştirme koşullarında bu perlitlerin genleştirilebilmesi için gerekli maksimum sıcaklığın $950{ }^{\circ} \mathrm{C}$ olduğu tespit edilmiştir. Ayrıca Batı Anadolu perlitlerinde saptanan toplam $\% 5$ oranındaki suyun, boşluk suyu dışındaki \%3,0-3,5 kadar kısmı gevşek bağlı su molekülleri olup $450{ }^{\circ} \mathrm{C}$ 'de kolaylıkla serbest kaldığı, kalan \%1,0-1,5'luk su, sıkı bağlı su olup $700^{\circ} \mathrm{C}-$ $950^{\circ} \mathrm{C}$ 'de serbest kaldığı belirlenmiștir. Dolayısıyla perlitlerin genleşmesinde etkili olan bu suyun efektif su olduğu tespit edilmiştir [3].

Öğütülmüş boyuta göre sınıflandırılmış ham perlit, türüne göre $700-1260{ }^{\circ} \mathrm{C}$ arasında sıcaklığı olan bir ortama verildiğinde içindeki kimyasal olarak bağlı suyun (\%2-\%6) buhar halinde çıkmasıyla çok kısa sürede mısır gibi patlayarak hacmi 4-25 kat artar. $\mathrm{Bu}$ şekilde genleștirilmiş perlit $400^{\circ} \mathrm{C}^{\prime} y e$ kadar ön Isıtmaya tabi tutulmasılyla perlitteki suyun \%80-\%90'ı buharlaşır. Kalan \%1,0-1,5'lik kısım genleștirme işlerinde eylemi olan aktif suyu meydana getirir [4].

Türkiye perlit rezervleri açısından dünyada sayılı ülkeler arasında olmasına rağmen endüstride perlit uygulamaları konusunda ARGE çalışmaları yetersiz kalmıştır. Özellikle yalıtım sektörünün birçok uygulamasında genleşmiş perlitler temel hammadde olarak kullanılmaktadır. Son 15 yılda perlitli alçı sıva, perlitli alçıpan panel üretimleri gibi bazı alanlarda büyük ölçüde genleşmiş perlit tüketimleri artmıştır. Bu bağlamada, ülkemizde tüketim merkezlerine yakın çok sayıda perlit genleştirme tesisleri kurulmuştur. Ancak bu tesislerde üretilen genleşmiş perlitlerin, üretim parametreleri ve genleşmeye etkileri konusunda yeterli sayıda bilimsel makaleye rastlanılmamıştır. Bu hususta çok eski yıllarda yapılan bazı bilimsel çalışmalarda sadece Batı Anadolu perlitlerinin genleştirilme sistematiği konusunda çok az sayıda çalıșmalara rastlanılmıștır. Ancak Orta Anadolu perlitlerin genleştirilme teknikleri üzerinde çok fazla bilimsel bilgiye rastlanılmamıştır. Sadece ticari anlamdaki genleştirme tesislerinin paylaştığı bilgiler görülmektedir.

Bu çalışmada Nevşehir bölgesi Acıgöl ve civarından temin edilen perlit agregaları üzerinde detaylı genleştirme deneyleri Isparta Uygulamalı Bilimler Üniversitesi, Teknik Bilimler Meslek Yüksekokulu, İnşaat bölümü laboratuvarlarında gerçekleştirilmiştir. Deneyler sonucunda hedef $250-400 \mathrm{~kg} / \mathrm{m}^{3}$ birim hacim ağırlık değerlerinde genleștirilmiş perlit malzemesini elde etmek amaciyla, gerekli koșullar, genleşme sıcaklı̆̆l, genleșme süresi (ısıtma süresi) ve tane boyutu değerlerine göre detay olarak irdelenmiştir. Böylece inovatif uygulamalar için özellikle de hafif beton, hafif blok üretimleri için teknik değerleri karşılamak üzere, hedef alınan birim hacim ağırlıklarda nitelikli genleştirilmiş perlit üretiminin gerçekleştirilmesi hedeflenmiştir. Bu amaçla yapılan optimizasyon çalışmalarının özellikle perlit üretimi sektörüne ve aynı zamanda bilim dünyasına katkı sağlayacağı düşünülmektedir.

\section{Nevşehir-Acıgöl Perlitlerinin Özellikleri}


Nevşehir ve civarında yer alan bölgedeki volkanitler Acıgöl-Göllüdağ volkanitleri olarak adlandırılmıștır. $\mathrm{Bu}$ volkanizma Üst Miyosen'de başlamış ve Kuvaterner'den tarihsel zamanlara kadar etkili olmuştur. Volkanizmanın Üst Miyosen'de andezitik lav akıntıları ve domlarla başladığını; Alt Pliyosen'de çeşitli tüfler, andezitik lavlar, ignimbritler oluştuğunu; Alt Kuvaterner'de (Pleyistosen) tüfler, riyolitik domlar ve lav akıntılarının yer aldığı; Üst Kuvaterner'de ise önce andezitler ve en son ürün olarak da bazaltların oluştuğunu saptamıştır $[5,6,7]$.

Orta Anadolu'daki Acıgöl (Nevşehir) civarındaki volkanizma, Kuvaterner sonlarına doğru yeniden asidik bir nitelik kazanarak domsal yapılar gelişmiş ve volkanik küller, obsidyen akıntıları, perlitler ve riyolitik lavlar ile bazaltik cüruflar oluşarak volkanik evrim tamamlanmıştır [8].

Acıgöl kalderası içindeki volkanik domlarda yer alan perlitik kayaçlarda yapılan incelemelerde toplam 450 milyon tonluk büyük bir perlit rezervi saptanmıștır [9].

Nevşehir-Acıgöl civarından temin edilen perlitlerin makro örnekleri incelendiğinde genellikle gri ve koyu gri renklerde olup, ince taneli ve inci parlaklığındadırlar. Mikroskop altında ince kesitleri incelendiğinde perlitik dokuda olup camsı hamur, plajiyoklaz, az miktarda kuvars ve plajiyoklaz kristalleri gözlenmiştir. Çok az olarak da biyotit kristali bulunmaktadır. Ayrıca bu çalışma kapsamında ham perlitlerin fiziksel ve kimyasal özellikleri analiz edilerek sonuçlar tablo 1 ve tablo 2'de verilmiştir.

Tablo 1. Ham perlit agregalarının fiziksel özellikleri

\begin{tabular}{ll}
\hline Özellik & \\
\hline Renk & Gri-koyu gri \\
Sertlik (Mohs) & $5-6$ \\
Ağırlıkça su emme(\%) & 1,40 \\
Özgül ağırlık (gr $\left./ \mathrm{cm}^{3}\right)$ & 2,39 \\
Ergime Noktası $\left({ }^{\circ} \mathrm{C}\right)$ & $1240-1350$ \\
\hline
\end{tabular}

Perlitte $\mathrm{Na}_{2} \mathrm{O}$ ve $\mathrm{K}_{2} \mathrm{O}$ toplam miktarının \%6-9 arasında olması oldukça önemlidir. Çünkü lavın viskozitesiyle bu değerler orantılıdır. Viskozite ise tozlașmayı önleyen, maddeyi bir bütün halinde tutan ve ufalanmadan genleşmeyi sağlayan etkendir. $\mathrm{Al}_{2} \mathrm{O}_{3}$ oranı ise viskoziteyi etkiler, $\mathrm{Na}_{2} \mathrm{O}+\mathrm{K}_{2} \mathrm{O}$ toplam oranı ile doğru orantılıdır. Perlitteki cam hamurunun kesin bir erime noktasının olmamasının ve geniș bir ergime aralığına sahip olması $\mathrm{Al}_{2} \mathrm{O}_{3}$ miktarından kaynaklanır [10].

Tablo 2. Ham perlit agregalarının kimyasal özellikleri

\begin{tabular}{|c|c|}
\hline $\begin{array}{c}\text { Kimyasal } \\
\text { Bileşen }\end{array}$ & (\%) \\
\hline $\mathrm{SiO}_{2}$ & 75,04 \\
\hline $\mathrm{Al}_{2} \mathrm{O}_{3}$ & 12,87 \\
\hline $\mathrm{Fe}_{2} \mathrm{O}_{3}$ & 0,78 \\
\hline $\mathrm{CaO}$ & 0,46 \\
\hline $\mathrm{MgO}$ & 0,15 \\
\hline $\mathrm{SO}_{3}$ & 0,01 \\
\hline $\mathrm{Na}_{2} \mathrm{O}$ & 1,60 \\
\hline $\mathrm{K}_{2} \mathrm{O}$ & 4,68 \\
\hline Kizdırma kaybı & 3,30 \\
\hline
\end{tabular}

Tablo 2 incelendiğinde Ham Perlit kayacının $\mathrm{SiO}_{2}$ miktarının \%75 civarında olması asidik ve silikat kökenli bir kayaç olduğunu göstermektedir. $\mathrm{Na}_{2} \mathrm{O}+$ $\mathrm{K}_{2} \mathrm{O}$ toplam oranı $\% 6,28$ olup, bu değerin $\% 6$ ile $\% 9$ arasında yer alması, genleșmenin gerçekleșmesinde önemli bir parametrenin sağlandığını da bize göstermiştir.

\section{Materyal ve Metot}

$\mathrm{Bu}$ çalışma kapsamında Orta Anadolu Bölgesi Nevşehir-Acıgöl civarından temin edilen ham perlitlerden elde edilen agregaların genleștirme deneyleri yapılmıştır.

Bölgeden temin edilen perlit kayaçları boyut küçültmek için önce laboratuvarda çeneli kırıcılardan geçirilerek, içerisindeki nemi atması amacıyla 110+/$5^{0} \mathrm{C}$ 'deki etüvde kondüsyonlanmıștır. Daha sonra kuru duruma gelen perlitler merdaneli kırıcılardan geçirilerek, farklı agrega boyutlarına ayrılması amacıyla eleme işlemlerine tabi tutulmuştur.

Bu çalışmada genleştirmede etken olan farklı üretim parametrelerinin, üretime ne ölçüde etki ettiğini belirlemek için; 7 farklı sıcaklık, 5 farklı agrega tane boyutu ve firında 5 farklı kalma süresi (genleștirme süresi) kullanılarak genleștirme deneyleri yapılmıștır. Genleștirme işlemi laboratuvar ortamında yer alan sabit fırında yapılmıştır. Nüve marka fırın ani sıcaklık şoklarına dayanıklı, 7 litre iç hacme sahiptir. Çalışmada genleştirilmiş perlit agregası her bir boyut için tek tek krozelere konularak fırına verilmiştir. Bu nedenle deneysel çalışma süresi çok uzun sürmüş ancak genleşme koşullarını detaylı bir şekilde incelemek açısından verimli olmuştur.

Deneysel çalışmada, genleştirme deneyi öncesi ve sonrası agregaların birim hacim ağırlıkları ASTM C 29 [11] ve TS EN 1097-6 [12] standardına göre belirlenmiştir. Daha sonra perlit agregalarının birim hacim ağırlık değerlerine göre, genleşme oranları hesaplanarak elde edilen bulgular grafiksel olarak yorumlanmıştır.

\section{Bulgular}

\subsection{Genleştirme Deneyleri}


Bu çalışmada genleștirme deneylerine geçmeden önce genleşme mekanizmasını daha iyi anlayabilmek için bazı bilimsel araștırmalar yapılmıștır. Yapılan bu araştırmalar neticesinde görülmüștür ki; ham perlitlerin bünyesinde ki efektif su ve perlitlerin yumuşama noktasının tespiti önemli bir etkendir. Özgenç, İ., 1993'e göre perlitlerin 450 C'ye kadar ön ısıtmaya tabi tutulmasıyla perlitler içerisinde bulunan \%2-5 oranındaki suyun, \%3-3,5'luk kısmı serbest kalıp, kalan \%1,0-1,5'luk kısmın genleşmede etkili olduğunu belirtmiştir. Dolayısıyla perlitlerin genleştirilmesinde bu miktar efektif su olarak tespit edilmiştir.

Perlitlerin kimyasal analizleri ile kızdırma kaybı değeri, perlitlerin özellikleri hakkında oldukça önemli fikirler verir [13]. Bu bağlamda, yaptığımız çalışmada kullanılan ham perlitlerin kimyasal bileșen analizi bize önemli bir fikir vermektedir. Kimyasal analiz sonucunda ham perlitlerin kızdırma kaybı \%3,30 olarak belirlenmiștir. Geriye kalan yaklaşık \%1,7’lik kısmı perlitlerimizin genleştirilmesinde etken olan efektif su (aktif su) miktarı olarak düşünülmektedir. Genleștirme mekanizmasının açıklanmasındaki ikinci bir faktör yumuşama noktasıdır. Sıcaklık yükseldikçe bünyedeki su kaybı yüzünden katılașma olana kadar agrega taneciği genişlemektedir. $\mathrm{Bu}$ yüzden perlit taneciğinin genişleme derecesi yumuşama noktasının üzerindeki sıcaklıklarda daha da artmaktadır. Ham perlitlerin yumuşama noktası gerek bilimsel çalışmalara göre gerekse ticari üretim yapan perlit genleştirme tesislerinin paylaştığı bilgilere göre $840^{\circ} \mathrm{C}$ dir. Bu çalıșmada ise perlitlerin yumuşama noktası elde edilen teknik bulgular değerlendirildiğinde 750 ${ }^{0} \mathrm{C}-850{ }^{\circ} \mathrm{C}$ arasında olduğu tespit edilmiștir. Çünkü genleştirme deneyleri sırasında bu sıcaklık değerlerinden sonra sıcaklık arttıkça tane boyutu ve ısıtma süresi bazında genleşme oranlarının yaklaşık 1,5 - 6 kat arasında daha fazla artış gösterdiği görülmüştür. $\mathrm{Bu}$ ön değerlendirme çalıșmalarından sonra ham perlit agregaları genleştirme deneylerine tabi tutulmuştur. Genleştirilmiş perlit agregası üretiminde etkin parametrelerin neler olduğunun bilinmesi ve bu parametrelerin genleşmeye etki derecesinin tespiti çok önemlidir. Genleştirme deneylerinde incelenen parametreler şunlardır:

Agregaların tane boyutları ( 5 farklı boyut; 8-16 mm, 4$8 \mathrm{~mm}, 2-4 \mathrm{~mm}, 1-2 \mathrm{~mm}$ ve $0-1 \mathrm{~mm}$ )

Fırın sıcaklığı (7 farklı sıcaklık; $100{ }^{\circ} \mathrm{C}$ artırmalı, 450 $\left.{ }^{0} \mathrm{C}-1050{ }^{\circ} \mathrm{C}\right)$

Fırında kalma süresi (ısıtma süresi) ( 5 farklı zaman; 1 dakika, 2 dakika, 3 dakika, 4 dakika ve 5 dakika) Deneysel çalışmalar sonucunda her bir parametrenin etkisi grafiksel analizlerle açıklanmaya çalışılmıştır. Böylece üretime etken parametreler ayrıntılı bir şekilde irdelenmiştir.

\subsubsection{Genleştirme sıcaklığı ve genleştirme süresinin etkisi}

Perlitlerin genleşme mekanizmasında etkili olan ham perlit bünyesindeki efektif su ve perlitlerin yumuşama noktası laboratuvar ön çalışmaları sırasında tespit edilmiştir. Daha sonra bu bölümde farklı boyutlardaki perlit agregalarında genleşmenin hangi sıcaklıkta etkili olduğu ve hangi sicaklıkta en iyi genleştiğini tespit edebilmek için farklı sıcaklıklarda deneyler yapılmıștır. Ayrıca genleștirme ișlemindeki önemli diğer bir konu ise ham perlitlerin firında ne kadar kalacağıdır. Bu nedenle farklı sıcaklık ve firında farklı kalma sürelerinde (ısıtma, genleştirme süresi) genleştirme deneyleri yapılmıştır. Böylece perlitlerin genleştirilmesinde etken olan optimum sicaklık ve süre bakımından değerlendirmesi yapılmıștır.

$\mathrm{Bu}$ çalışmada, ham perlit agregaları kırıcıdan geçirildikten sonra 5 farklı granülometride boyutlandırılmıștır. Boyutlandırılan ham perlit agregaları ayrı ayrı $450^{\circ} \mathrm{C}-1050^{\circ} \mathrm{C}$ arasinda $\left(100{ }^{\circ} \mathrm{C}\right.$ artırmalı) ve fırında 5 farklı kalma süresi $(1 \mathrm{dk} ., 2 \mathrm{dk}$., $3 \mathrm{dk} ., 4 \mathrm{dk} ., 5 \mathrm{dk}$.) uygulanarak genleştirme işlemine tabi tutulmuștur. Genleștirme deneyi öncesi birim hacim ağırlıkları belirlenen agregaların, genleștirme sonrası da birim hacim ağırlıkları ASTM C 29 ve TS EN 1097-6 standardına göre belirlenmiştir. Böylece agregaların genleşme oranları tespit edilerek, elde edilen bulgular grafiksel olarak yorumlanmıştır (Şekil 1-Şekil 5). Çalışmada elde edilen teknik bulguları daha net bir şekilde yorumlayabilmek için 8-16 mm, 4-8 $\mathrm{mm}$ ve $2-4 \mathrm{~mm}$ boyut aralığındaki perlit agregaları grubu "iri agregalar", 0-1 mm, 1-2 mm boyut aralığındaki perlit agregaları grubu ise "ince agrega" olarak isimlendirilmiştir. Bu bağlamda, agrega boyut bazında en ideal genleşme sıcaklığı ve genleşme süresi de tespit edilmiştir.

Genleștirme deneylerine ilk olarak 8-16 mm boyut aralığındaki perlit agrega serisinden başlanmıştır. Agrega serisi bünye kaybetme suyu olarak bilinen 450 ${ }^{0} \mathrm{C}$ 'den itibaren $1050^{\circ} \mathrm{C}$ 'ye kadar firında 5 farklı kalma süresinde (1dk., $2 \mathrm{dk} ., \quad 3 \mathrm{dk} ., \quad 4 \mathrm{dk}$. ve $5 \mathrm{dk}$.) genleştirmeye tabi tutulmuştur. Şekil 1'de görüldüğü gibi sıcaklık ve fırında kalma süresi arttıkça genleşme oranı artmaktadır. $450^{\circ} \mathrm{C}-750^{\circ} \mathrm{C}$ arasında tam anlamıyla bir genleşme gözlenmezken, $750{ }^{\circ} \mathrm{C}$ 'nin 4. dakikasından sonra \%11,17'lik bir genleșme oranı ile dikkate değer bir genleşmenin başladığı gözlenmiştir. $850{ }^{\circ} \mathrm{C}$ sicaklıkta ise 2 dakikadan sonra hızlı bir trendle genleşmenin arttığı görülmektedir.

8-16 mm tane boyut aralığında en fazla genleşme 1050 ${ }^{0} \mathrm{C}$ 'de \%60,50 oranında gerçekleșmiștir. Ancak $950{ }^{\circ} \mathrm{C}$ sicaklıkta da 1 dakikadan 5 dakikaya kadar olan firında kalma sürelerinde $1050{ }^{\circ} C^{\prime}$ ye yakın oranlarda genleşme gerçekleşmektedir. 


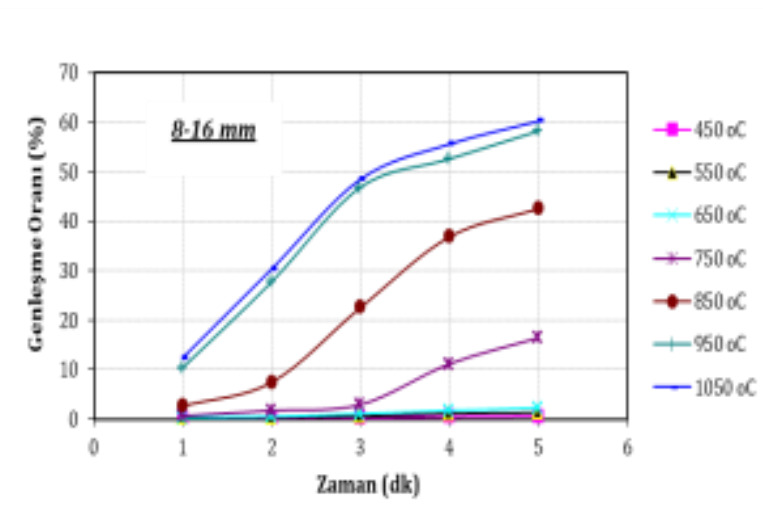

Şekil 1. 8-16 mm boyut aralı̆̆ındaki perlit agregalarının fırında kalma süresine göre genleşme oranı değișimi.

$950{ }^{0} \mathrm{C}^{\prime}$ de en fazla genleşme 5 dakikada \%58,03 civarındadır. Örneğin 8-16 $\mathrm{mm}$ tane boyut aralığındaki perlit agregalarının \%20’lik bir genleşme sağlayabilmesi için $850^{\circ} \mathrm{C}^{\prime}$ de 3 dakika civarında firında kalması gerekirken, $950{ }^{\circ} \mathrm{C}$ ve $1050{ }^{\circ} \mathrm{C}$ 'de 1,5 dakikalık bir süre yeterlidir.

4-8 mm boyut aralığındaki perlit agregaları da diğer iri agrega boyutlarında olduğu gibi artan sıcaklıkta ve artan fırında kalma sürelerinde genleştirme işlemine tabi tutulmuştur. Bu boyuttaki agregalarda $450^{\circ} \mathrm{C}$ $750^{\circ} \mathrm{C}^{\prime} \mathrm{da}$ dikkate değer bir genleşme gözlenememiştir. 8-16 mm tane boyutlu agregalarda olduğu gibi bu boyut agregalarda da $750{ }^{\circ} \mathrm{C}^{\prime}$ den itibaren genleşmenin başladığı söylenebilir. $\mathrm{Bu}$ sıcaklıkta dikkati çeken genleşme oranı değeri 4 . dakikadan itibaren gerçekleşmektedir. $750 \quad{ }^{\circ} \mathrm{C}$ sıcaklıkta, fırında kalma süresinin 4. dakikasında genleşme oranı \%11,78 olarak tespit edilmiş ve Şekil 2'de görüldügü gibi sıcaklık ve süre arttıkça genleşme oranlarının arttığı görülmüștür.

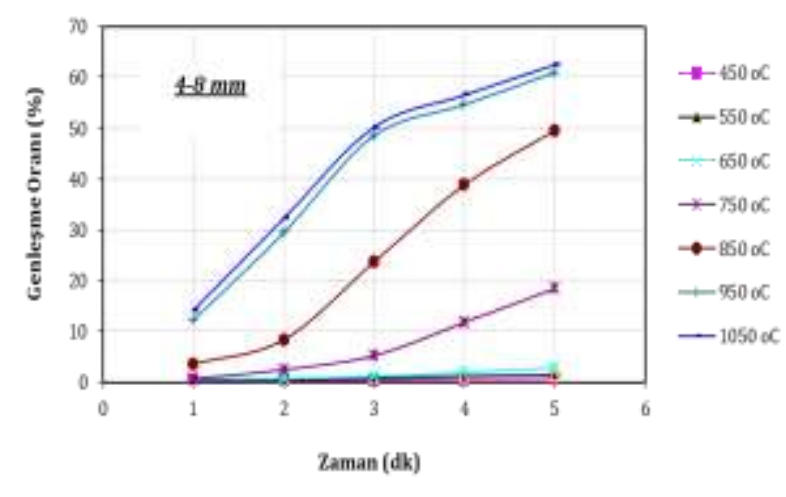

Şekil 2. 4-8 mm boyut aralığındaki perlit agregalarının fırında kalma süresine göre genleşme oranı değişimi.

4-8 $\mathrm{mm}$ boyut aralığındaki perlit agregalarında ise en fazla genleşme $1050{ }^{\circ} C^{\prime}$ de 5 dakikalık firında kalma süresinde \%62 civarındadır. Şekil 2'de görüldügü gibi perlit agregalarının $950{ }^{\circ} \mathrm{C}$ sicaklıktada $1050{ }^{\circ} \mathrm{C}$ 'ye paralel bir şekilde genleşme performansı gösterdiği dolayısıyla firında kalma süresi arttıkça genleşmenin arttığı görülmektedir.

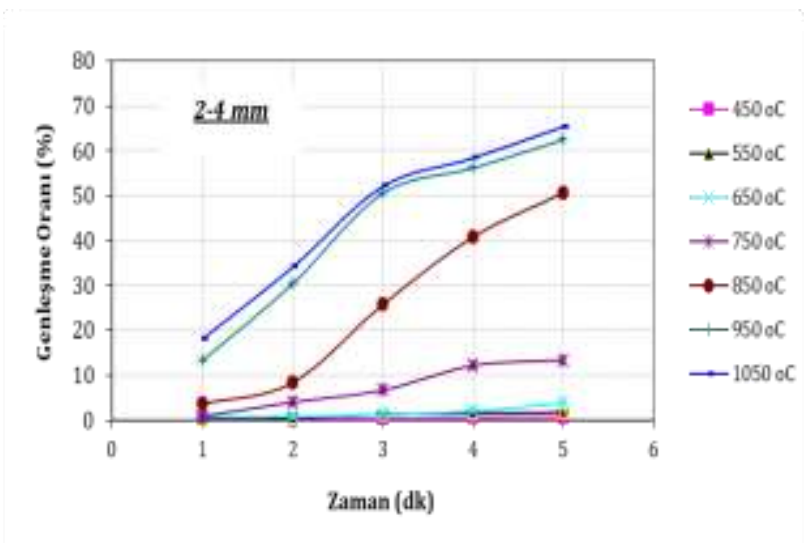

Şekil 3. $2-4 \mathrm{~mm}$ boyut aralığındaki perlit agregalarının fırında kalma süresine göre genleşme oranı değișimi.

Diğer bir serimiz ise $2-4 \mathrm{~mm}$ tane boyutlu perlit agregalarımızdır. Bu boyut serisinde perlit agregaları diğer boyutlarda olduğu gibi $450{ }^{\circ} \mathrm{C}-1050{ }^{\circ} \mathrm{C}$ arasında ve firında 5 farklı kalma sürelerinde (1dk.-5dk.) genleştirme işlemine tabi tutulmuştur. 4-8 mm boyutundaki agregaların genleşme performansları ile benzer özellik göstermektedir. Bu seride de dikkate değer bir genleşmenin $750{ }^{\circ} \mathrm{C}$ sıcaklığın 4. dakikasında gerçekleşmiştir. Bu sıcaklık ve sürede genleşme oranı \%12,20 olarak tespit edilmiş ve Şekil 3'de görüldüğü gibi sıcaklık ve süre arttıkça genleşme oranlarının arttığı görülmüştür.

Sicaklığın $850 \quad{ }^{0} C^{\prime}$ sinde ise diğer iri agrega boyutlarında olduğu gibi $2-4 \mathrm{~mm}$ tane boyutlarında da fırında kalma süresinin 1. dakikasından 5. dakikasına kadar genleşme oranlarının arttığı görülmüştür. 850 ${ }^{0}$ C'de 5 dakikada genleşme oranı \%50,65 olarak tespit edilmiştir. $950{ }^{\circ} \mathrm{C}^{\prime}$ de en fazla genleşme 5 dakikada $\% 62,50$ civarındadır, diğer iri agrega boyut aralıklarında görüldüğü bu boyuttaki agregalarda da en fazla genleşme $1050{ }^{\circ} \mathrm{C}$ nin 5 . dakikasinda gerçeklemiş ve genleşme oranı \%65,40 olarak belirlenmiştir.

Diğer bir serimiz ise $1-2 \mathrm{~mm}$ tane boyutlu perlit agregalarımızdır. $\mathrm{Bu}$ boyut serisinde perlit agregalarında sıcaklık arttıkça genleşme oranları artmıştır. Ancak bu serinin diğer iri agrega gruplarından farkı $450{ }^{\circ} \mathrm{C}$ 'de küçük ölçekli genleşme başlamıştır. Gözle görülür yaklaşık \%10 civarında bir genleşme oranı ise $650{ }^{\circ} \mathrm{C}$ 'de başlamıştır. Şekil 4'de görüldüğü gibi bu agrega serisinde $450^{\circ} \mathrm{C}^{\prime} \mathrm{den}$ $1050^{\circ} \mathrm{C}^{\prime}$ ye kadar sıcaklık arttıkça genleşme oranları artmıştır. Ancak bu seride $450^{\circ} \mathrm{C}-850{ }^{\circ} \mathrm{C}$ arasındaki sıcaklıklarda dikkatimizi çeken bir olgu ise, genleşmenin 2. dakikaya kadar lineer bir trendle artış gösterdiği belirlenirken 2. dakikadan sonra ise 5 . dakikaya kadar genleşme oranlarında azalma tespit edilmiştir. $950{ }^{0} \mathrm{C}^{\prime}$ den sonra ise 1 dakikadan 5 dakikaya doğru, yani firında kalma süresi arttıkça genleșme oranları azalmıştır. Diğer bir ifadeyle $950^{\circ} \mathrm{C}$ ve $1050{ }^{\circ} \mathrm{C}$ de ise en yüksek genleșme 1. dakikalarda 
gerçekleșmiștir. $950^{\circ} \mathrm{C}$ 'de genleșme oranı 1. dakikada $\% 30,20$ iken $1050^{\circ} \mathrm{C}^{\prime}$ de ise $\% 32,50$ civarındadır.

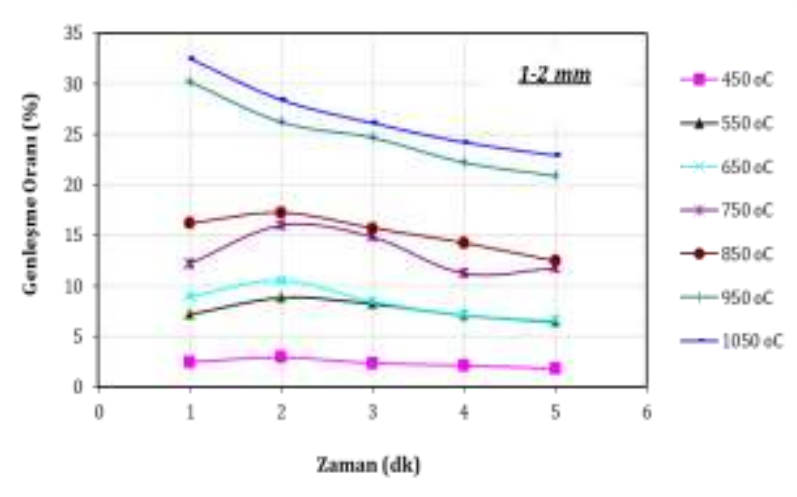

Şekil 4. 1-2 mm boyut aralığındaki perlit agregalarının fırında kalma süresine göre genleşme oranı değişimi.

1-2 mm boyut aralığında ki perlit agregalarında en fazla genleşme diğer agrega gruplarında (8-16 mm, 4$8 \mathrm{~mm}$ ve $2-4 \mathrm{~mm}$ ) olduğu gibi $1050{ }^{\circ} \mathrm{C}$ sicaklıkta gerçekleşmiştir. Diğer agrega gruplarında bu sıcaklıkta en fazla genleşme oranı yaklaşı $\% 60$ civarında 5 dakikada tespit edilmiştir. Bu seride ise (1$2 \mathrm{~mm}$ ) en fazla genleşme oranı yaklaşık \%35 civarında 1 dakikada gerçekleşmiştir. Ancak firında kalma süresi 1 dakikadan daha az bir süre olur ise genleşme oranının daha fazla olacağı yorumunu yapmak mümkündür (Şekil 4).

1 mm'nin altındaki boyutlarda perlit agregalarında sıcaklık arttıkça genleşme oranları artmıştır (Şekil 5). $\mathrm{Bu}$ seride de 2-4 mm boyutlarındaki agregalarda olduğu gibi $450{ }^{\circ} \mathrm{C}^{\prime}$ de genleşme başlamıştır.

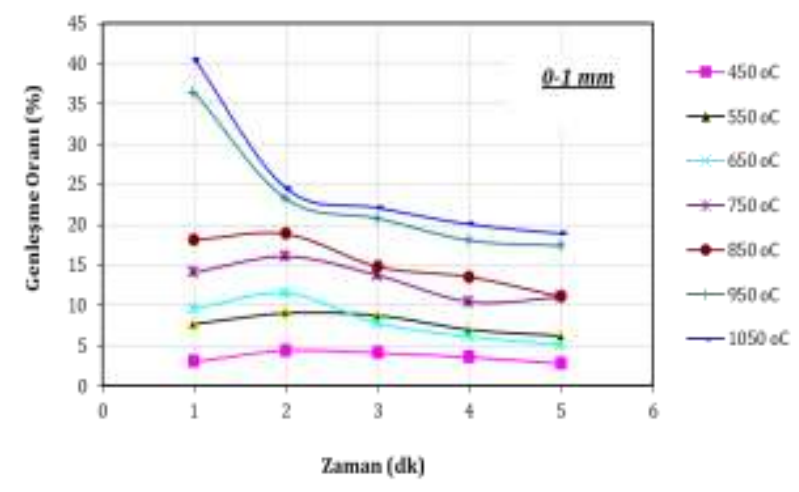

Şekil 5. $1 \mathrm{~mm}$ boyut altındaki perlit agregalarının fırında kalma süresine göre genleșme oranı değişimi.

Şekil 5'de görüldüğü gibi sıcaklık arttıkça genleşme oranları artmış ancak firında kalma süreleri değişmiştir. Bu seride de 1-2 mm boyut aralığındaki agregalarda görüldüğü gibi $450^{\circ} \mathrm{C}-850{ }^{\circ} \mathrm{C}$ arasındaki sıcaklıklarda genleşmenin 2. dakikasına kadar lineer bir trendle artış gösterdiği belirlenirken 2. dakikadan sonra ise 5. dakikaya kadar genleşme oranlarında azalma tespit edilmiştir. $950{ }^{\circ} \mathrm{C}$ ve $1050{ }^{\circ} \mathrm{C}$ sıcaklıklarda genleşme oranları açısından birbirine paralel bir genleşme gözlenirken en yüksek genleşme $1050{ }^{\circ} \mathrm{C}$ 'de 1 . dakikada $\% 40,50$ oranında tespit edilmiştir. Genleşmenin 5. dakikasında ise aynı sıcaklıkta bu oran \%18,90’a düşmüştür. Buradan şöyle bir sonuç çlkarmak mümkündür. $2 \mathrm{~mm}$ boyut altındaki perlit agregaların genleşebilmesi için uzun sürede fırında bekletilmesine gerek yoktur. 1 dakikalık bir zaman diliminde \%40 civarı bir genleşme sağlanabilmektedir. Ayrıca iri agregalarda $650{ }^{\circ} \mathrm{C}^{\prime} \mathrm{ye}$ kadar kayda değer bir genleşme gözlenemezken, ince agregalarda ise bu sıcaklığa kadar \%3,5-11,5 civarında bir genleşme oranı tespit edilebilmiştir.

$\mathrm{Bu}$ çalışmada, 5 farklı boyuttaki ham perlit agregalarına 7 farklı sıcaklıkta $\left(450{ }^{\circ} \mathrm{C}-1050{ }^{\circ} \mathrm{C}\right)$ ve 5 farklı sürede (1dk.-5dk.) genleştirme işlemi uygulanmıştır. Genleştirme sıcaklığı ve süresinin etkisini tespit etmek amacıyla, iri ve ince agrega olarak sınıflandırdığımız (İri agregalar: 8-16 mm, 4-8 mm, 2$4 \mathrm{~mm}$, İnce agrega: $1-2 \mathrm{~mm}$ ve $0-1 \mathrm{~mm}$ ) her boyut agrega için elde edilen bütün teknik bulgular Şekil 1Şekil 5 arasında grafiksel olarak yorumlanmıştır. Özetle bir değerlendirme yapmak gerekirse deneyi yapılan bütün boyut agregalar için genleşme sıcaklığı arttıkça genleşme oranlarının arttığı tespit edilmiştir. Özellikle iri boyut agregalarda bütün sıcaklıklarda (özellikle $750{ }^{\circ} \mathrm{C}$ ve sonrası) genleșme süresi arttıkça genleşme oranı artmaktadır. Ancak ince boyut agregalarda $\quad 450 \quad{ }^{\circ} \mathrm{C}-850^{\circ} \mathrm{C}$ arasındaki tüm sıcaklıklarda 2 dakikaya kadar genleşme artmakta, 2 dakikadan sonra genleşme oranları yavaş yavaş düşmektedir. $950{ }^{\circ} \mathrm{C}$ ve $1050{ }^{\circ} \mathrm{C}$ 'de genleşme oranının en yüksek olduğu zaman dilimi 1 dakikadır. 1 dakikadan sonra iri agregaların tersine genleşme oranları fırında kalma süresi arttıkça düşmektedir. Ham perlitlerin yumuşama noktasının $750{ }^{\circ} \mathrm{C}$ ve sonrası olduğu bilinmektedir. Dolayısıyla iri agregaların yumuşama noktası üzerinde bir sıcaklıkta daha fazla genleştiği net olarak görülmektedir. Diğer bir ifadeyle, iri agregalarda yumuşama noktası altındaki bir sıcaklıkta dikkate değer bir genleşme görülmemektedir. İnce agregalarda ise $450^{\circ} \mathrm{C}^{\prime} \mathrm{de}$ genleşme başlamaktadır. Dolayısıyla ince agregalarda yumuşama sıcaklığının altındaki sıcaklıklarda genleşme başlamıştır. Ön ısıtma ısısı olarak geçen bu sıcaklıkta bünyedeki suyun bir kısmının buharlaşması geriye kalan efektif suyun ise daha düşük sıcaklıkta ince boyut agregaları genleștirmede aktif rol aldığı söylenebilir. İnce boyuttaki agregalar ağırlıklarına göre yüzeyleri daha geniştir. Dolayısıyla ısının nüfuz etmesi gereken kalınlık daha azdır. Bu nedenle iri agregalara göre daha düşük fırında kalma sürelerinde genleșebilmektedir. Deneysel çalışmalar neticesinde en fazla genleşmenin iri agregalarda $1050{ }^{\circ} \mathrm{C}^{\prime}$ de 5 dakikada \%60-\%65 civarında iken, ince agregalarda özellikle $1 \mathrm{~mm}$ boyut altındaki perlit agregalarında $1050{ }^{\circ} C^{\prime}$ de 1 dakikada \%40,50 civarındadır. Dolayısıyla ince agregalar için fırında kalma süresi 1 dakikanın altına indirildiğinde daha fazla genleşme oranına sahip olabileceğini söyleyebiliriz. 
Ayrıca yapı malzemelerinde özellikle yalıtım amaçlı uygulamalarda ana hammadde olarak genleșmiș perlitlerin kullanıldığı bilinmektedir. $\mathrm{Bu}$ nedenle bu çalışma kapsamında özellikle yalıtım harçlarında kullanılabilecek nitelikli genleşmiş perlit üretilmesi mümkündür. Bu bağlamda hedef değer olarak 250$400 \mathrm{~kg} / \mathrm{m}^{3}$ birim hacim ağırlığında genleşmiş perlitlerin üretilmesi tasarlanmıştır. Sözü edilen birim hacim ağırlıkta perlitlerin üretilmesinde en uygun üretim parametresi sıcaklık ve süre bazında özellikle iri boyut agregalarda $850^{\circ} \mathrm{C}$ sıcaklıklarda $4 \mathrm{dk}$. firında kalma süresi ile gerçekleșebilmektedir. İnce agregalarda ise $1050^{\circ} \mathrm{C}$ de 2 dakika firında kalma süresi ile hedef birim hacim ağırlık değerlerinde genleşmiş perlit agregası elde edilebilmektedir. Daha düşük birim hacim ağırlıklarda genleşmiş perlit agregası elde etmek istiyorsak iri veya ince boyut agregalarda sicaklık $1000{ }^{\circ} C^{\prime}$ nin üzerinde olması gereklidir. Sadece iri agregalarda daha uzun süre fırında kalması gerekirken ince agregalarda fırında kalma süresi daha düşük olmalıdır.

Bütün serilerde en fazla genleşme $1050^{\circ} \mathrm{C}$ sıcaklıkta gerçekleşmektedir. Ancak üretim bazında üretim sıcaklığının artması ekonomik olarak istenmemektedir. Özellikle genleşmiş perlit üreticileri $1000{ }^{\circ} C^{\prime}$ nin üzerinde ki sıcaklık değerlerini enerji maliyetlerini dolasıyla üretim maliyetlerini artıracağından dolayı tercih etmemektedirler. $\mathrm{Bu}$ nedenle bu çalışma kapsamında en iyi genleşme $1050^{\circ} \mathrm{C}$ 'de elde edilse de üretim açısından ekonomik olması da önem arz etmektedir. Bu bağlamda en ideal genleşme sıcaklığı $950^{\circ} \mathrm{C}$ olarak tespit edilmiştir.

Genleștirme öncesi ham perlit agregalar ve agregaların genleştirme deneyleri esnasındaki görünümü ile genleştirme sonrası perlit agregalarının görünümü sırasıyla Şekil 6, Şekil 7 ve Şekil 8'de verilmiştir.

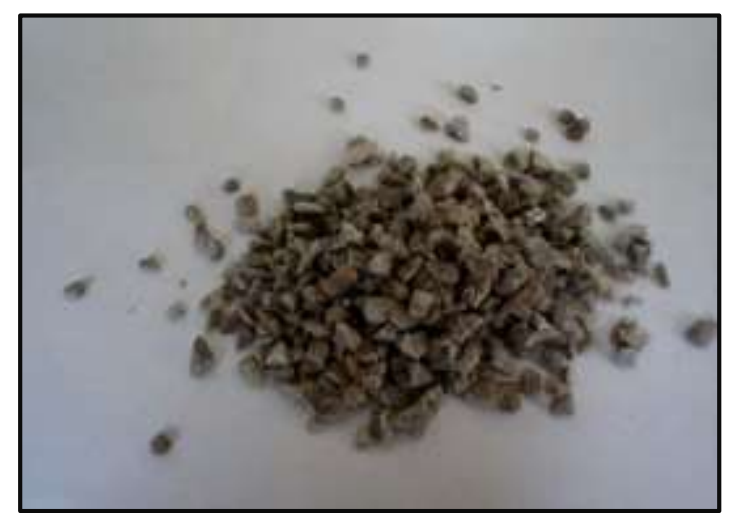

Şekil 6. Boyutlandırılmış ham perlit agregasının görünümü

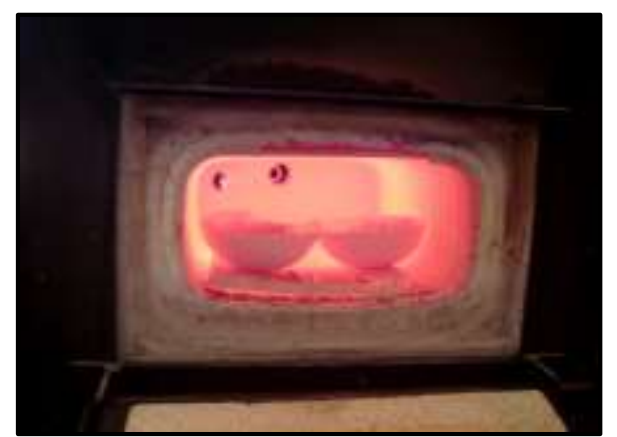

Şekil 7. Agregaların yüksek sıcaklıkta fırında genleșmesi sırasındaki görünümü

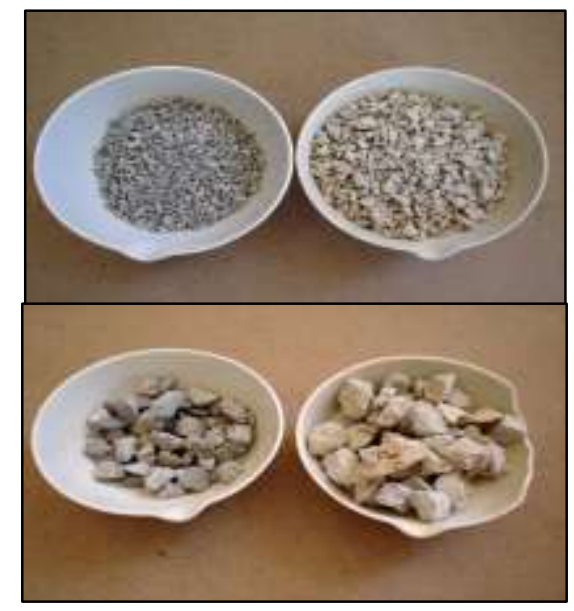

Şekil 8. Farklı tane boyutlarında genleştirilmiş perlit agregalarına ait bir görünüm

\subsubsection{Agrega Tane Boyutunun Etkisi}

Ham perlitlerin tane iriliği de genleşmeye etki etmektedir. Agrega tane boyutu ile genleşme süresi arasındaki ilişkiyi daha iyi görebilmek amacıyla bu bölümde $950{ }^{\circ} \mathrm{C}$ sıcaklıkta 5 farklı sürede genleştirilen perlitlerin tane boyutuna karşı genleșme oranları arasındaki ilișkiyi gösteren grafik Şekil 9'da verilmiștir.

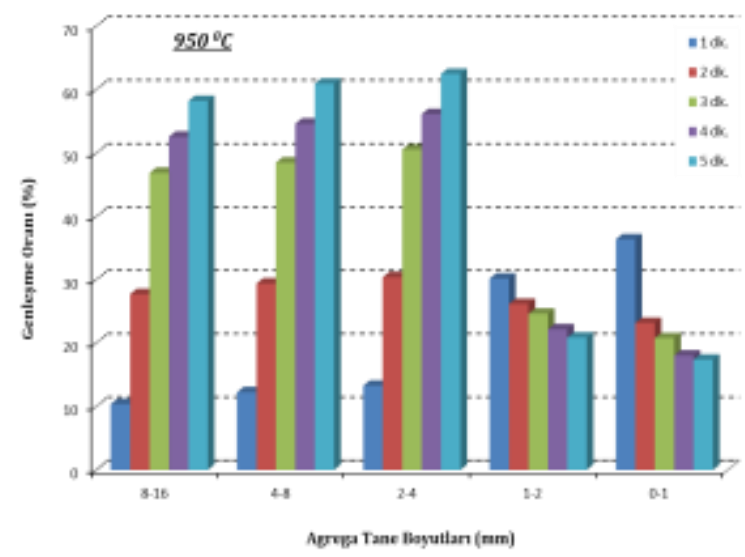

Şekil 9. $950^{\circ} \mathrm{C}^{\prime}$ de genleştirilen bir perlitin tane boyutu ve genleşme oranı ilișkisi 
İri taneli agregalarda sıcaklığın tamamen agrega içine nüfuz edebilmesi için, nispeten uzun süre ısıtılması yani daha uzun süre firında kalması gerekir. Şekil 6'da görüldügü gibi iri agrega gruplarında (8-16 mm, 4-8 $\mathrm{mm}, 2-4 \mathrm{~mm}$ )en fazla genleşme 5. dakikalarda gerçekleşmektedir. Fırında kalma süresi arttıkça genleşme oranı artmaktadır. İnce agregalarda (1-2 $\mathrm{mm}, 0-1 \mathrm{~mm}$ ) ise 1. dakikalarda genleşme oranları daha fazladır.

Ayrıca ince agregalarda firında kalma süresi arttıkça genleşme oranları kademeli bir şekilde düşmektedir. Bunun nedeni, genleştirme süresi uzadıkça ince agregalar içerinde bulunan su yumuşama noktasına erişmeden kısmen uçuyor ve dolayısıyla genleşme oranı yavaş yavaş düşmeye başlıyor. Başka bir deyişle ince agregalarda 1 dakikadan daha kısa bir sürede genleşme oranı en fazla miktara ulaşıyor, ancak firında kalma süresi arttıkça bu oran yavaş yavaş azalmaya başlıyor. Bu grafiksel analizden de anlaşllacağı üzere tane boyutuna bağlı olarak sayısal anlamda hangi oranda genleşme isteniyorsa o oranda fırında kalma süresini ayarlanabilir. Örneğin $950{ }^{0} \mathrm{C}$ 'de \%35-40 civarı bir genleşme için 8-16 mm, 4-8 mm, 2-4 mm agregalar için 3 dakikalık bir genleștirme süresi olması gerekirken, $2 \mathrm{~mm}$ altı agrega boyutlarında 1 dakikalı bir süre yeterlidir. Ayrıca ince boyut agregalarının \%50 civarlarında bir genleşme oranını yakalayabilmesi için 1 dakikadan daha kısa bir sürede hatta yaklaşık 20-40 saniye arası bir sürede genleşebileceği ön görülmüştür.

\section{Tartışma ve Sonuç}

$\mathrm{Bu}$ çalışma kapsamında Orta Anadolu Bölgesi Nevşehir-Acıgöl civarından temin edilen ham perlitlerden genleştirilmiş perlit agregası üretimi için genleşmeye etken parametreler incelenerek en uygun üretim koşulları tespit edilmeye çalışılmıştır. Öncelikle ham perlitlerin fiziksel ve kimyasal özellikleri analiz edilerek genleşme mekanizması hakkında ön fikir edinilmiştir. Ham perlitler kırıcılardan geçirilerek farklı tane boyutlarında sınıflandırılmıştır. Daha sonra laboratuvar ölçekli olarak genleştirme deneylerine başlanmıştır. Genleştirme deneyleri 7 farklı sıcaklık, 5 farklı agrega tane boyutu ve firında 5 farklı kalma süresi olarak gerçekleştirilmiştir. Bütün bu parametrelerin genleștirmeye etkisi ayrı ayrı analiz edilerek bulgular bölümünde detaylı olarak irdelenmiştir. Bu çalışmada iri agrega ve ince agrega olarak değerlendirilen tüm serilerde sıcaklık arttıkça genleşme oranının arttığı tespit edilmiştir. İri agregalarda $750^{\circ} \mathrm{C}$ sıcaklıkta, ince agregalarda ise $650^{\circ} \mathrm{C}$ den itibaren gözle görülür bir genleşme gözlenmiştir. Örneğin \%10'luk bir genleşme iri agregalarda $750^{\circ} \mathrm{C}$ 'nin 4 . dakikasında gerçekleşirken ince agregalarda $650^{\circ} \mathrm{C}$ sıcaklık ve 2 dakika fırında kalma süresi ile gerçekleşmektedir. Diğer bir ifade ile $750^{\circ} \mathrm{C}$ sicaklığa kadar iri agregalar ince agregalara göre daha yavaş genleşmeye devam etse de, iri agregalarda $850^{\circ} \mathrm{C}$ sicaklıktan itibaren genleşme oranları hızlı bir şekilde yükselmeye başlamıştır.

Perlit agregalarının genleşmesini ısıtma süresi veya fırında kalma süresi açısından değerlendirecek olursak; iri agregalarda en iyi genleșme 5 dakikada gerçekleşirken, ince agregalarda ise yüksek sıcaklıkta en ideal genleşme 1 dakika sürede gerçekleşmektedir. Genleştirme deneylerinde bütün boyutlarda en fazla genleşme $1050^{\circ} \mathrm{C}$ sıcaklıkta gerçekleşmektedir. $\mathrm{Bu}$ çalışmada en fazla genleşme oranı \%65 ile 2-4 mm tane boyutunda $1050^{\circ} \mathrm{C}$ sicaklık ve 5 dakika firında kalma süresiyle gerçekleşmiştir. Ancak $1000^{\circ} \mathrm{C}$ 'nin üzeri sıcaklıklar ekonomik olmayacağı için bütün boyutlar için yakın genleşme oranı $950^{\circ} \mathrm{C}^{\prime} \mathrm{de}$ tespit edilmiştir. Dolayısıyla genleştirme deneyleri sonrası en optimum genleştirme sicaklığı $950^{\circ} \mathrm{C}$ olarak belirlenmiştir.

Bu çalışmada diğer bir inceleme parametresi ise 250$400 \mathrm{~kg} / \mathrm{m}^{3}$ birim hacim ağırlıklarında genleştirilmiş perlit agregası üretimi için gerekli sıcaklık ve sürenin tespitidir. Deneysel çalışmalarda hedef birim hacim ağırlıkta genleşmiş perlit agregaları üretimi, iri boyut agregalarda $850^{\circ} \mathrm{C}$ sıcaklıklarda $4 \mathrm{dk}$. fırında kalma süresi ile gerçekleşirken, ince agregalarda ise $1050^{\circ} \mathrm{C}$ de 2 dk'lık ısıtma süresinde gerçekleşmektedir. Daha düşük birim hacim ağırlıkta genleşmiş perlit agregası üretiminin ise $1000^{\circ} \mathrm{C}$ 'nin üzerindeki sicaklıklarda gerçekleşeceği görülmüştür.

Ayrıca genleştirme işlemleri sırasında önemli bir ayrıntı dikkatimizi çekmiştir. Farklı tane büyüklüklerinde agregalar aynı anda fırında genleştirme işlemine tabi tutulursa, olumsuz sonuçlar vermektedir. Çünkü agregaların farklı büyüklükte olmaları eşit muamele görmelerini zorlaştırır. Sıcaklığın iri ve ince tanelere etkisi farklı olacağından, genleşme oranları ve firında kalma süreleri değişik olacaktır. İnce agregaların ağırlıklarına göre yüzey alanları daha geniş olduğu için ısının nüfuz etmesini gerektiren kalınlıkları azdır, dolasıyla iri tanelere oranla yüksek sıcaklıkta daha kısa sürede genleşebilmektedir. $\mathrm{Bu}$ nedenle iri ve ince agregaları aynı anda fırında genleștirmemek gerekir. Hangi boyut aralığında genleştirilmiş perlit agregası üretmek istiyorsak sadece o tane boyutundaki agregaları firına beslemek gerekir.

$\mathrm{Bu}$ çalışma laboratuvar ölçekli olarak gerçekleştirilmiştir. Elbette tesis bazında üretim parametrelerinde değişiklikler olabileceği gibi tespit edilen sıcaklık ve sürelerde bir miktar değişiklik söz konusu olabilir. Yine bu tip tesislerde genleștirme işleminin yapılacağı fırın tasarımları da çok önemlidir. Ancak bu çalışmada, genleşme mekanizmasının iyi etüd edilmesi açısından perlitlerin laboratuvarda ön incelemeleri yapılmış, genleştirmede etkili olacak bütün parametreler irdelenmiş ve sonuçları paylaşılmıştır. Böylece genleşmiş perlit üreticileri ve yeni açlacak tesis bazındaki üreticilere fikir vermesi, 
genleștirme faktörlerinin dikkate alınması ve tesislerin ona göre dizayn edilmesi amaçlanmıştır. Ayrıca bilimsel literatüre de katkı sağlaması hedeflenmiştir.

\section{Kaynakça}

[1] Türkiye Madenciler Derneği (TMD), Ağustos, 2015. Sektörden Haberler Bülteni, sayı, 57, İstanbul.

[2] Breese, Richard O.Y. and Barker, James, M. 1994. Perlite Industrial Minerals and Rocks, Society for Mining, Metallurgy and Exploration, Inc., Littleton, Colorado.

[3] Özgenç, İ. 1993. Perlitler içindeki suyun kimyasal yapısı ve bu yapının genleşme özelliğine etkisi. Jeoloji Mühendisliği Dergisi, s.42, 60-63, Ankara.

[4] Toraman, Y.Ö. vd. 2018. Mikro-perlit üretiminde genleştirme firını ve üretim prosesleri. Uluslararası katılımlı Kapadokya Yerbilimleri Sempozyumu Bildiriler kitabı, s.55-58, 24-26 Ekim, Niğde.

[5] Batum, İ., 1975. Petrographische und geochemische Untersuchungen in den volkangebieten Göllüdağ und Acıgöl (Zentralanatolien-Türkei). Doktora Tezi, AlbertLudwigs Üniv.,Freiburg, 102 s, Almanya.

[6] Batum, İ., 1978a. Nevşehir güneybatısındaki Göllüdağ ve Acıgöl volkanitlerinin jeokimyası ve petrolojisi, 1978a, Yerbilimleri, 4/1-2,70-88.

[7] Batum, İ., 1978b. Nevşehir güneybatısındaki Göllüdağ ve Acıgöl yöresi volkanitlerinin jeolojisi ve petrografisi. Yerbilimleri, 4/1-2,50-69.

[8] Ercan, T., vd. 1991. Acıgöl (Nevşehir) yöresindeki senozoyik yaşlı volkanik kayaçların petrolojisi. MTA Dergisi, 113, 31-44, Ankara.

[9] Öngür, T., 1978. Nevşehir kalderası: TJK 32. Bilimsel ve Teknik Kurultayı Bildiri özetleri Kitabı, 43

[10] Kırımer, H., 1976. Perlit, TMMOB Maden Mühendisleri Odası, Bilimsel Madencilik Dergisi, cilt, 15, sayı 6, s37-44.

[11] ASTM C 29/C29M-17a, 2017. Standard Test Method for Bulk Density ("Unit Weight") and Voids in Aggregate, ASTM İnternational, USA.

[12] TS EN 1097-6. 2013. Agregaların Mekanik ve Özellikleri için Deneyler Bölüm 6: Tane Yoğunluğu ve Su Emme Oranının Tayini, TS, Ankara.

[13] Oktay, 0. 1969. Perlit, Perlit, TMMOB Maden Mühendisleri Odası, Bilimsel Madencilik Dergisi, cilt 8, sayı, 4, s213-222. 